\title{
Tax Revenue, Capital Formation, and Economic Growth in Nigeria
}

\author{
A. Abiola Oluwatobi ${ }^{1}$, F. Adegbie Festus ${ }^{1} \&$ O. Ogundajo Grace ${ }^{1}$ \\ ${ }^{1}$ Babcock University, Ogun State, Nigeria \\ Correspondence: O. Ogundajo Grace, Babcock University, Ogun State, Nigeria. Tel: 234-706-526-3796.
}

Received: September 28, 2020

Accepted: November 5, $2020 \quad$ Online Published: January 3, 2021

doi:10.5430/rwe.v12n1p101

URL: https://doi.org/10.5430/rwe.v12n1p101

\begin{abstract}
Economic growth drivers aimed at stimulating and stabilizing the economies of the countries to engender sustainable growth. Studies have shown that Nigeria has been plagued with stunted and faltering economic growth over the years. Tax and other relevant macroeconomic policies are implemented by the government to smoothen out economic fluctuations but this has not been fully harnessed. A causal-effect study was conducted between tax revenue, gross fixed capital formation and economic growth using a 38-year time series data from 1981 to 2018 derived from CBN statistical bulletin. It was found that tax revenue (TR) had significant positive effect on Gross Domestic Product and Gross Fixed Capital Formation (GFCF) significantly controls the relationship between TR and GDP. It is evidenced that the country relied heavily on taxes as major source of revenue. The study recommended that government should widen its tax net, creates expansionary measures to enhance its tax revenue in order to boost its GDP. The government should also create an enabling environment for economy diversifications in order to increase revenue generated via other means than taxes in order to spur economic growth and avoid over-reliance on taxes.
\end{abstract}

Keywords: economic growth, gross fixed capital formation, Nigeria, tax revenue

\section{JEL Classification: H21, 040}

\section{Introduction}

Economic growth of a nation has proved unattainable globally, especially among African Countries (Osho \& Efuntade, 2019). According to the reporting figures by National Bureau of Statistics, (2018) and African Development Bank Group (2020) report, Nigeria's annual GDP growth rate averaged 1.26\% between 2010 and 2019. The country's highest GDP growth rate of $10.59 \%$ during the period occurred in the third quarter of 2010, while the country recorded the lowest GDP growth rate of $-13.97 \%$ in the first quarter of 2016. World Bank 2018 data showed that annual GDP growth rate of Nigeria which was $8.01 \%$ in 2010 decreased to $-6.12 \%$ in $2015,5.31 \%$ in 2011 and $4.23 \%$ in 2012 . The decline in the country GDP growth rate reversed temporarily to $6.67 \%$ in 2013 before further decreased to 4.31 in $2014,2.65 \%$ in 2015 and $-1.62 \%$ in 2016. In 2018, Nigeria GDP attained marginal positive growth of $0.81 \%$, which increased to $1.94 \%$ in 2018 . Nigerian economy attained $9.23 \%$ on quarter GDP growth in the third quarter of 2019 , reflecting an increase of $3.02 \%$ growth from the immediate preceding quarter, and the fastest quarterly growth since the third quarter of 2012 (National Bureau of Statistics, 2018; World Bank, 2018; African Development Bank Group, 2020).

According to African Development Bank, (2019) decaying and underinvestment in physical infrastructure, tariff and non-tariff barriers to trade, ineffective leadership, corruption, over-reliance on oil, rising unemployment, weak educational systems, gender discrimination, poor health care systems, external dependency and inflation are among the factors common across most of the African continent with which Nigeria cannot be left out. They constrained the productivity and economic potentials (Adams, 2019).

According to Amadi and Alolote (2019) tax and other relevant macroeconomic policies are implemented by the government of a country to smoothen out economic fluctuations and achieve sustainable economic growth and other macroeconomic objectives. Stability in economic growth manifests in sustainable increase in Gross Domestic Product (GDP), which is usually measured in terms of monetary value of aggregate goods and services legally produced in a country during a given year (Wosowei, 2013). It is a measure of the extent of macroeconomic stability in a country. Macroeconomic stability subsists when a country witnesses sustainable increase or constant growth in its Gross Domestic Product (Asaolu, Olabisi, Akinbode \& Alebiosu, 2018). 
African region is identified as a region with the largest number of economies below the least expected ratio of tax revenue to Gross Domestic Product of 15\%. Certainly, this level of association between tax revenue and GDP is considered insufficient to fuel the elementary needs of the citizen being the primary function of the State. Tax revenue-GDP of Nigeria was 5.7\%, which is lower than the $17.2 \%$ average for 26 African countries by $11.5 \%$, and also lower than the 22.8\% average for the Latin American countries and the OECD average of 34.2\% (OECD, 2019).

Faced with these challenges, government has carried out several reforms to the tax system, for example, Finance Act 2019 (with effect from February 2020); Increase in Value Added Tax, recent introduction of consumption tax by some States, joining the ECOWAS Free Trade Zone committee and signing the agreement. All these reforms aimed at greater tax revenue mobilization for increased and sustainable economic growth through increased aggregate savings, investment and output (Gbato, 2017).

The reforms are not driven by the desires to lower the tax burden; rather, they seek to foster appropriate tax structure capable of increasing tax revenue base so as to strengthen government's productive expenditure and, boost economic growth. Despite all the efforts of the government and various reforms implemented, Nigeria tax system has not been fully harnessed to reach the growth level that the nation desired and benchmarked against African Continent's average. Thus, this paper examined how gross fixed capital formation influenced the effect of tax generated revenue and economic growth in Nigeria.

\section{Literature Review}

\subsection{Review of Concepts}

Economic growth, often regarded as Gross National Product (GNP) growth, is the extent to which the output of the economy in terms of production of goods and services grow (Ironkwe \& Agu, 2019). Gale and Samwick (2016) explain economic growth as the expansion of the supply side of the economy and of potential Gross Domestic Product. Ogho (2007); Okwu, Oseni, Aberu and Obiakor (2017); Wosowei (2013), The Organisation for Economic Co-Operation and Development (OECD, 2020) and International Monetary Fund (IMF) publication (2020) described Gross Domestic Product in terms of the total monetary value of goods and services produced in a country within residents of the country, irrespective of countries of origin. It is referred to as one of the key measures used to determine the strength of the economy of a nation (Jhingan, 2004); and it is also used for the appropriate indicator for cross-country comparison of global economic growth rates (World Bank, 2016). In this context, GDP is measured as real GDP at current rate in absolute values (dollars)

Tax revenue, as an integral part of government total revenue, is derived from the payment of compulsory levies imposed on the legal activities and incomes of entities of a country (Lin \& Jia, 2019). Tax revenue is a major component of total revenue of the government in every society of the world (Azubike, 2009). Ola (2001), Jhingan (2004) explained that raising revenue to meet government expenditure, redistribute income and wealth, and manage the economy is the main purpose of tax. Herbert, Nwarogu, and Nwabueze (2018) asserted that financing the infrastructural structure of any nation depends on the tax system in relation to effective assessment, collection and remittance for proper accountability by the designated agencies. In this context, Tax revenue is expressed as the total revenue generated from tax at federal level.

Gross Fixed Capital Formation (GFCF) is a macroeconomic concept; it measures the value of acquisitions of new or existing fixed assets, that is, accumulation of capital goods, electricity, infrastructures, equipment, tools, and transportation assets by the business sector, governments and "pure" households (excluding their unincorporated enterprises) less disposals of fixed assets. GFCF shows something about how much of the new value added in the economy is invested rather than consumed (Dladla \& Khobai, 2018). Countries need capital goods to replace the older ones that are used to produce goods and services. Inability of any nation to replace its capital goods after its useful life, could lead to decline in its production (Tuovila, 2019). Generally, the economic aggregate income responds positively and swiftly to improvements in the capital formation of an economy; and producing more goods and services can lead to an increase in national income levels, and thus improves economic growth.

\subsection{Theoretical Underpinning}

In relation to theories, this study's finding is consistent with the proposition of endogenous growth theory propounded by Romer (1986), with modification by Lucas (1988) and updated by Romer (1990). The theory emphasizes that growth in the economy arises from intentional action of all economic agents. Economic agents in the context of this study means collective effort of all the nation's citizens. One of the statutory responsibilities of every citizen is to pay tax, and the stewardship role of the government is to judiciously utilize this fund for socio-economic 
development. The growth of every nation is a joint effort of all the economic agents of such nation, that is, the leaders and the citizens.

\subsection{Empirical Review}

In the study of Ukpabi (2019) on the impact of indirect taxes on economic growth in Nigeria using time series data from 1981 to 2018 and Ordinary Least square (OLS) method of analysis; it was reported that there exist an ample long run and short run relationships between the various components of indirect taxation and economic growth. Similar findings were reported by Ionkwe and Agu (2019) which investigated the relationship between total tax revenue and economic growth in Nigeria using time series data from 1986-2016. Akintoye and Tashie (2013) denoted that the Nigeria Government had to raise revenue through taxation in order to meet its expenditure, which has a time to expend much. Section 141 of the 1963 constitution of Federal Republic of Nigeria made specific provision for shared for development purpose in each state.

In contrast, Iorpev, Azende and Matthew (2019) in their study on the effect of tax revenue on Nigerian economic growth using time series data from 2002 to 2017; discovered that individual components of taxes in Nigeria have no significant effect on economic growth but the total tax revenue significantly impacted the economy. Osho and Efuntade (2019) reported insignificant effect of all other forms of taxes on economic growth except VAT which had significant positive effect while the overall relationship reflected that tax revenue significantly affected economic growth of Nigeria. Azubike and Onukwube (2019) considered the effect of tax revenue using time series data for 15 years between 2002 and 2016, and discovered that in aggregate, tax revenue impacted significantly on economic growth of Nigeria. Samuel, Adewole and Idih (2019) employed simple linear regression analysis of an eleven years (2003-2013) time series data to explore the implications of tax revenue on economy growth in Nigeria; it was reported in their study that tax revenue was not a predominant factor impacting on the Nigerian economy as an insignificant positive effect was obtained. Oshiobugie and Akpokerere (2019) studied economic growth in relation to personal income tax and company income tax from 2000 to 2017, exploring ex-post facto research design within ordinary least squares (OLS) regression framework, the results showed negative and insignificant effect of the tax revenue components on economic growth.

Amos, Uniamikogbo and Aigienohuwa (2017) discovered that company and personal taxes as well as some other tax variants have positive effect on economic growth in Nigeria. In the same vein, Asaolu et al., (2018) examined the relationship between tax revenue and economic growth in Nigeria from 1994 to 2015 adopting a descriptive and historical research design. The result of their Auto Regressive Distributed Lag (ARDL) Regression revealed a long run and short run relationship between tax revenue and economic growth. Similar study conducted between 1995 and 2015 by Edewusi and Ajayi (2019) supported the findings of Asaolu et al., (2018). Uzoka and Chiedu (2018) carried out related study during the period of 1997-2016; and reported that company income tax has significant effect on economic growth. Similar result was also obtained by Egbunike, Emudainohwo and Gunardi (2018) in their study conducted on Nigerian and Ghanaian economies. Contrarily, Abomaye-nimenibo, Michael and Friday (2018) while empirically analysing tax revenue and economic growth in Nigeria from 1980 to 2015 and Cornelius, Ogar and Oka (2016) examined the impact of tax revenue on the Nigerian economy from 1986 to 2010 reported an insignificant relationship between petroleum profit tax, company income tax, custom excise duties and economic growth in Nigeria.

In line with divergence conclusions of the reviewed studies; this paper hypothesized that tax revenue insignificantly affects economic growth while gross fixed capital formation does not significantly control the relationship between tax revenue and economic growth in Nigeria.

\section{Methodology}

A causal-effect relationship was conducted to investigate the controlling effect of fixed capital formation in the relationship between tax revenue and economic growth of Nigeria; adopting an ex-post facto method of design. Statistical figures for gross fixed capital formation (GFCF), Tax revenue and Gross Domestic Output from 1981-2018 were educed from Central bank of Nigeria (CBN) Statistical bulletin, 2018 and World Bank Reports (2020). Tax revenue and Gross Domestic product were measured in \$billions while GFCF as a percentage of real GDP was used. Relevant descriptive and inferential analyses were conducted with the aid of E-views 14 and the results presented in section 4.0 of this paper. The study established both short-run and long run models situating the relationship between the variables as:

VAR Equation:

$$
\Delta \mathrm{GDP}_{\mathrm{t}}=\beta_{0}+\sum_{i=1}^{p-2} \beta_{1} \Delta \mathrm{TR}_{\mathrm{t}}+\epsilon_{\mathrm{t}}
$$


OLS long run Equation:

$$
\Delta \mathrm{GDP}_{\mathrm{t}}=\beta_{0}+\beta_{1} \Delta \mathrm{TR}_{\mathrm{t}}+\mu_{\mathrm{t}}
$$

VAR Equation:

OLS long run Equation:

$$
\Delta \mathrm{GDP}_{\mathrm{t}}=\beta_{0}+\sum_{i=1}^{p-1} \beta_{1} \Delta \mathrm{TR}_{\mathrm{t}}+\sum_{i=1}^{p-1} \beta_{2} \Delta \mathrm{GFCF}_{\mathrm{t}}+\epsilon_{\mathrm{t}}
$$

$$
\Delta \mathrm{GDP}_{\mathrm{t}}=\beta_{0}+\beta_{1} \Delta \mathrm{TR}_{\mathrm{t}}+\beta_{2} \Delta \mathrm{GFCF}_{\mathrm{t}}+\mu_{\mathrm{t}}
$$

Where: GDP means Gross Domestic product; TR as tax Revenue while GFCF represented Gross Fixed Capital Formation

\section{Results and Explanations}

\subsection{Pre-estimation Analysis}

This entails analysing the characteristics of the series in the distribution in relation to the Mean, Median, Maximum, Minimum, Standard deviation, Skewness, Kurtosis and Jacque-Bera (for normality test); and also, the test for stationary of the series using the Augmented Dickey-Fuller Unit Root Test. The summary of the descriptive statistics of the variables are presented in Table 1 while the Unit Root Stationary test is shown in Table 2 respectively.

\subsubsection{Descriptive Statistics}

Table 1. Descriptive statistics

\begin{tabular}{lllllllll}
\hline Measures & Mean & Median & Max. & Min. & Std. Dev. & kewness & urtosis & Jarque-Bera (Prob) \\
\hline GDPNG & 184.59 & 96.24 & 568.50 & 27.75 & 166.39 & 0.89 & 2.33 & $5.73(0.057)$ \\
\hline TRNG & 23.98 & 14.84 & 72.43 & 3.41 & 21.76 & 0.97 & 2.59 & $6.18(0.046)$ \\
\hline GFCFGDPNG & 36.22 & 35.32 & 89.39 & 14.17 & 19.57 & 0.99 & 3.62 & $6.78(0034)$ \\
\hline
\end{tabular}

Source: Researcher's Computation (2020)

The Gross Domestic Product (GDP) and taxation revenue (TR) of Nigeria stood at an average 184.59 and 23.98 respectively implying that the GDP of Nigeria is averagely equal to $\$ 184.59$ billions in the 38 years study (1981 2018) while TR averagely equates $\$ 23.98$ within the same period. The Gross Fixed Capital Formation as a percentage of GDP stood at 36.22 percent revealed that within the 38years of this study, GFCF is averagely computed at $36.22 \%$ of GDP. The highest amount of yearly generated taxation revenue within the 38 years of this study was $\$ 72.43$ billions while the highest generated GDP of Nigeria within the considered period was $\$ 568.5$ billion

The mean and the median values of all the series in the distribution deviated from each other except for Gross Fixed Capital Formation; this is an indication of asymmetric distribution, which is the series are not normally distributed. On the contrary, the probability of the Jarque-Bera for GDP of 0.06 , being greater than 0.05 (5\% level of significance) proved that the GDP is normally distributed. Although the statistical figures for the skewness revealed that all the series are positively skewed because the figures are greater than 0 which is the threshold; while the kurtosis showed that GDP and TR are leptokurtic (being less than the threshold of 3) while GFCF is platykurtic being greater than 3 as threshold).

\subsubsection{Result of the Stationary Test}

Stationary test was conducted to examine the behaviour (stability or predictability) of series over the period under study, whether the series is trending either downward or upward; and also in case of the presence of shocks within the period, to determine if series adjust to shocks that may exist in the short run or in the long run or the shocks effect are likely to be permanent. Unit Root Test (Augmented Dickey Fuller (ADF)/Phillip Perron is used to test for stationary in the series and the result is presented in Table 2. 
Table 2. Result of the unit root test

\begin{tabular}{|c|c|c|c|c|c|c|c|}
\hline \multirow[t]{2}{*}{ Series } & \multirow{2}{*}{$\begin{array}{l}\text { Equation } \\
\text { Specification }\end{array}$} & \multicolumn{3}{|c|}{ Critical Values } & \multirow{2}{*}{$\begin{array}{l}\text { ADF test at } \\
\text { level (Prob) } \\
\text { T-cal (Prob) }\end{array}$} & \multirow{2}{*}{$\begin{array}{l}\text { ADF test at } 1^{\text {st }} \\
\text { Diff. (Prob) } \\
\text { T-cal (Prob) }\end{array}$} & \multirow[t]{2}{*}{ Remarks } \\
\hline & & $1 \%$ & $5 \%$ & $10 \%$ & & & \\
\hline \multirow[t]{3}{*}{ GDP } & None & -2.63 & -1.95 & -1.61 & $0.18(0.73)$ & $-3.70(0.00)$ & $\mathrm{I}(1)$, Intercept \\
\hline & Intercept & -3.67 & -2.96 & -2.62 & $-2.13(0.24)$ & $-3.77(0.01)$ & \\
\hline & Intercept \& Trend & -4.23 & -3.54 & -3.20 & $-2.39(0.38)$ & $-3.84(0.03)$ & \\
\hline \multirow[t]{3}{*}{$\overline{T R}$} & None & -2.63 & -1.95 & -1.61 & $-0.84(0.34)$ & $-6.57(0.00)$ & I(1), Intercept \\
\hline & Intercept & -3.62 & -2.94 & -2.61 & $-1.51(0.52)$ & $-6.49(0.00)$ & \\
\hline & Intercept \& Trend & -4.23 & -3.54 & -3.20 & $-2.28(0.69)$ & $-6.40(0.00)$ & \\
\hline \multirow[t]{3}{*}{ GFCF } & None & -2.63 & -1.95 & -1.61 & $-3.87(0.00)$ & $-4.28(0.00)$ & $\mathrm{I}(0)$, Intercept \\
\hline & Intercept & -3.62 & -2.94 & -2.61 & $-3.42(0.02)$ & $-4.66(0.00)$ & \\
\hline & Intercept \& Trend & -4.23 & -3.54 & -3.20 & $-3.31(0.08)$ & $-5.36(0.00)$ & \\
\hline
\end{tabular}

Source: Researcher's Computation, (2020)

Having estimated the stationary status of all the series in the models, both tax revenue and Gross Domestic Product were stationary at the same order of integration (at first difference at 10 per cent significant level), while Gross Fixed Capital Formation became stationary at level "I(0)". It implies that GFCF is predictable in its natural form while TR and GDP are stationary when transformed.

To verify further the relevance of the model and to examine the nature of relationship among the series in the model, there is need to test for co-integration. Co-integration test enables the study to know if the series would converge with time (in the long run), even if there are shocks in the short run, which may affect movement in the individual series. Therefore, Vector Auto Regression (VAR) analysis, optimal lag length was determined using VAR Lag Order Selection Criteria, and Johansen Co-integration test were conducted.

\subsubsection{Optimal Lag Length Selection Criteria (Nigeria)}

This paper carried out the test to determine the appropriate lag length for the main estimation and diagnostic tests using VAR Lag Order Selection test as depicted in Table 3.

Table 3. Optimal lag length selection criteria output

\begin{tabular}{|c|c|c|c|c|c|c|}
\hline \multicolumn{7}{|c|}{ Tax Revenue and GDP } \\
\hline Lag & $\log \mathrm{L}$ & LR & FPE & AIC & $\mathrm{SC}$ & HQ \\
\hline 0 & -158.3448 & NA & 730.9225 & 9.432048 & 9.521834 & 9.462668 \\
\hline 1 & -150.1844 & $14.88069 *$ & 479.8304 & 9.010850 & $9.145529 *$ & 9.056779 \\
\hline 2 & -148.4845 & 2.999980 & $460.7666^{*}$ & $8.969674 *$ & 9.149246 & $9.030913^{*}$ \\
\hline 3 & -147.7896 & 1.185318 & 469.6067 & 8.987624 & 9.212089 & 9.064173 \\
\hline \multicolumn{7}{|c|}{ Tax Revenue, GFCF, and GDP } \\
\hline$\overline{\mathrm{Lag}}$ & $\log \mathrm{L}$ & LR & FPE & AIC & $\mathrm{SC}$ & $\mathrm{HQ}$ \\
\hline 0 & -168.3014 & NA & 795.7256 & 9.516744 & 9.648704 & 9.562802 \\
\hline 1 & -159.0951 & $16.36674^{*}$ & $504.6592 *$ & $9.060839 *$ & $9.236786^{*}$ & $9.122249 *$ \\
\hline
\end{tabular}

Source: Researcher's Computation, (2020)

The results of the optimal lag length selection using Sequential Modified LR test (LR), Final Prediction Error (FPE), Akaike information criterion (AIC), Schwarz information criterion (SC) and Hannan-Quinn information criterion (HQ) revealed that out of the five criteria, two selected lag 1 while the other three results showed lag 2; the discrepancies among the five criteria could be referenced in the stationary tests conducted which automatically selected different lag for each of the series. Therefore, the study concluded that the lag 2 is the appropriate lag length because three of the five criteria supported lag 2. Having selected lag 2, it implies that the GDP would not be 
impacted by the immediate occurrence change in the tax revenue until after two accounting years (Liew, 2004), this would only take effect within a short while as the shock would regulates itself over time. With the inclusion of GFCF as control variable into the model, lag one length was the significant result considering the results of the five criteria; which implies that the impact of tax revenue and Gross Fixed Capital Formation would not be felt immediately on the GDP of Nigeria but the effect would manifest a year after, that is, the preceding year values of tax revenue and GFCF affects the current values of GDP.

\subsubsection{Co-integration Test}

Two types of test were considered under the Johansen Test (Trace test and Max-Eigen statistics) and the results presented in Table 4.

Table 4. Johansen co-integration test (trace and max-eigen statistics)

\begin{tabular}{lllll}
\hline Tax Revenue and GDP & & & \\
\hline Hypothesized No. of CE(s) & Eigenvalue & Critical Value @ 5\% & Trace Stat (Prob) & Max-Eigen Stat (Prob) \\
\hline None* & 0.337 & 3.841 & $14.36(0.00)$ & $14.36(0.00)$ \\
\hline Unrestricted Co-integrating Coefficients & DGDP(0.033) & \\
\hline Unrestricted Adjustment Coefficients (alpha): & DGDP (-13.39) & \\
\hline Tax Revenue, GFCF, and GDP & & \\
\hline Hypothesized No. of CE(s) & Eigenvalue & Critical Value @ 5\% & Trace Stat (Prob) & Max-Eigen Stat (Prob) \\
\hline None* & 0.329 & 3.841 & $13.94(0.00)$ & $13.94(0.00)$ \\
\hline Unrestricted Co-integrating Coefficients & & DGDP(0.03) & \\
\hline Unrestricted Adjustment Coefficients (alpha): & DGDP (-13.12) & \\
\hline
\end{tabular}

Source: Researchers Computation (2020)

The existence of co-integration was evidenced in the results of the Johansen co-integration tests carried out on both econometric equations. This indicated that the series would converge in the long run, irrespective of the presence of shock in the short run estimates.

\subsection{Diagnostic Tests}

Residual diagnostics and stability diagnostics were carried out. The residual diagnostic test conducted entails residual normality test, serial correlation test, and heteroskedasticity test. Ramsey RESET test and recursive estimates were conducted as stability tests. The results of these tests were presented in Table 5.

Table 5. Residuals diagnostic tests

\begin{tabular}{|c|c|c|c|c|c|}
\hline & & & Without GFCF & & With GFCF \\
\hline & & Statistics: & & Prob & \\
\hline \multirow[t]{6}{*}{ Normality test } & \multirow[t]{3}{*}{$\begin{array}{lll}\text { VAR Residual Normality } \\
\text { Tests }\end{array}$} & Skewness & $\begin{array}{l}0.42\left(\mathrm{Chi}^{2}=\right. \\
0.299)\end{array}$ & 0.74 & $\begin{array}{l}0.39 \\
0.95)\end{array}\left(\mathrm{Chi}^{2}=0.33\right.$ \\
\hline & & Kurtosis & $\begin{array}{l}3.40\left(\mathrm{Chi}^{2}=\right. \\
0.253)\end{array}$ & 0.62 & $\begin{array}{l}3.42\left(\mathrm{Chi}^{2}=0.60\right. \\
0.27)\end{array}$ \\
\hline & & Jarque-Bera & 1.33 & 0.514 & 1.22 \\
\hline & \multirow{3}{*}{$\begin{array}{l}\text { Histogram Normality Tests } \\
\text { (see Figure 1) }\end{array}$} & Skewness & 0.42 & & 0.27 \\
\hline & & Kurtosis & 3.40 & & 2.53 \\
\hline & & Jarque-Bera & 1.33 & 0.514 & 0.99 \\
\hline Serial Correlation Test & Breusch-Godfrey LM Test & & $\mathrm{F}_{(1,34)}=14.25$ & 0.00 & $\mathrm{~F}_{(1,33)}=11.85$ \\
\hline
\end{tabular}




\begin{tabular}{llllll}
\hline $\begin{array}{l}\text { Heteroskedasticity } \\
\text { Test }\end{array}$ & Breusch-Pagan-Godfrey & $\mathrm{F}_{(1,35)}=3.305$ & 0.08 & $\mathrm{~F}_{(2,34)}=1.706$ & 0.197 \\
\hline Stability Test & Ramsey RESET Test & T-Stat $=0.637$ & 0.53 & T-Stat $=0.449$ & 0.66 \\
& & F-Stat $=0.405$ & 0.53 & F-Stat $=0.202$ & 0.66 \\
\cline { 2 - 6 } & Recursive Coefficients & See Figure 2 & & & \\
\hline
\end{tabular}

Source: Researcher's Work (2020)

Since the series are stationary in the same order of integration, thus VAR was adjudged suitable for the analysis while the OLS was also used to determine the long run estimation. Residual diagnostic tests (normality, serial correlation, and heteroskedasticity) were carried out using VAR Residual Normality Tests; Histogram normality test; Breusch-Godfrey Serial Correlation LM Test; Breusch-Pagan-Godfrey Heteroskedasticity Test, and Durbin-Watson Test.

The null hypothesis of VAR Residual Normality Tests and Histogram normality test (Figure 1) state that the residuals are normal. The results using skewness statistics, kurtosis and Jarque-Bera statistics where the skewness statistics for both tests approximately equal to the threshold of zero (0) which are (0.42 and 0.39), and $\rho$-values of 0.74 and 0.33 which is greater than 5\%(0.05) chosen significant level implies that the residuals are normal. Also, considering the Kurtosis with statistical value approximately close to the threshold of 3 (3.40, and 3.42) and $\rho$-values of 0.62 and 0.60 which is greater than 5\% (0.05) chosen significant level implies that the residuals are normal. Similarly, the result of the Jarque-Bera test for both techniques with $\rho$-values of 0.514 and 0.543 , which is greater than 5\% (0.05) chosen significant level implies that the residuals are normal. Therefore, the null hypotheses are thereby accepted. The residuals of the series in the model are normally distributed and thus suitable for estimating linear relationship.

The existence of correlation problem among the residuals of the model was determined using Breusch-Godfrey Lagrangian Multiplier Test, while Breusch-Godfrey heteroskedasticity Test and Durbin-Watson Test were conducted to ensure that the residuals are stationary (invariant) over time; the $\rho$-values of these tests with 0.00 , and 0.197 respectively showed that there exist a serial correlation among the residuals of the model, but no heteroskedasticity problem in the model. The model stability test was carried out using Ramsey RESET Test and Recursive estimation (recursive Coefficients). The result of the Ramsey RESET test indicated that the equation specified is stable $(\rho=$ $0.66>005$ ); likewise the graphs of the recursive estimations (Figure 2) with the estimation lines lying within the lower and upper bounds, confirmed the stability of the model.
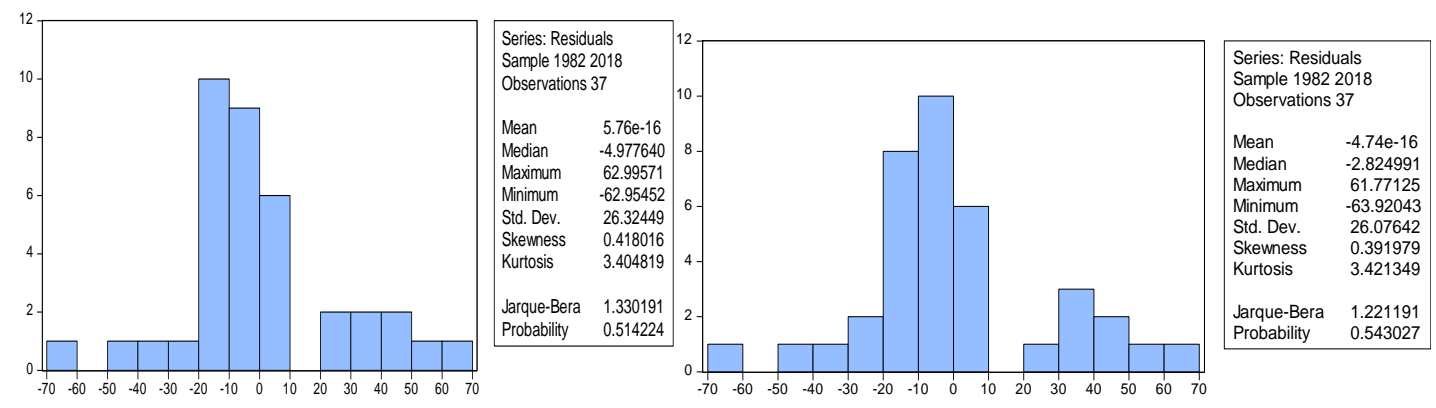

Figure 1. Histogram normality tests

Source: Researcher's Work (2020) 


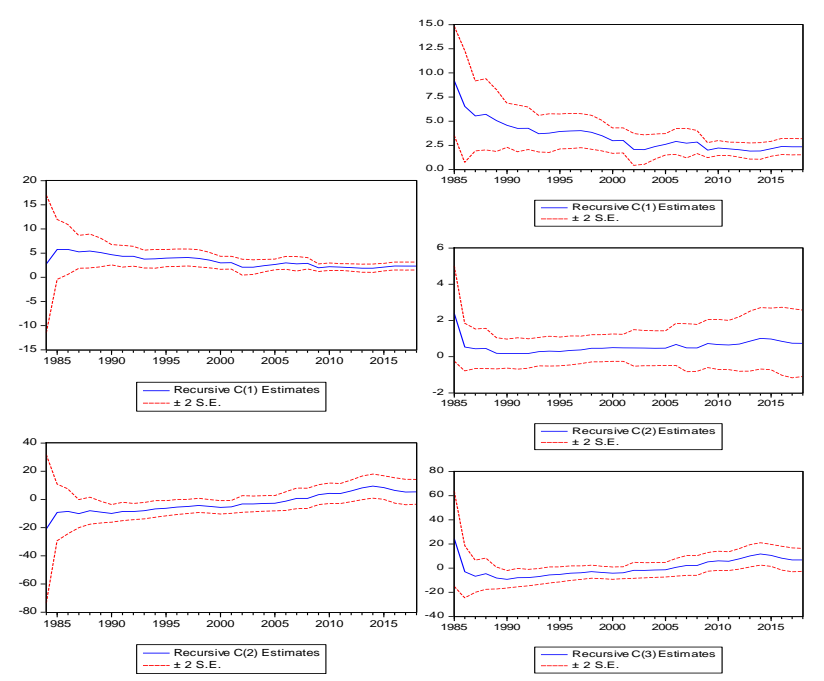

Figure 2. Recursive estimation: recursive coefficients

Source: Researcher's Work (2020)

\subsection{Granger Causality Test (Nigeria)}

Table 6. Granger causality test

\begin{tabular}{llll}
\hline Null Hypothesis: & Obs & F-Statistic & Prob. \\
\hline DTRNG does not Granger Cause DGDPNG & 35 & 3.67702 & 0.0373 \\
\hline DGDPNG does not Granger Cause DTRNG & & 1.59017 & 0.2206 \\
\hline DGFCFGDPNG does not Granger Cause DGDPNG & 35 & 0.15420 & 0.8578 \\
\hline DGDPNG does not Granger Cause DGFCFGDPNG & & 0.93362 & 0.4043 \\
\hline DGFCFGDPNG does not Granger Cause DTRNG & 35 & 0.39001 & 0.6804 \\
\hline DTRNG does not Granger Cause DGFCFGDPNG & & 0.32048 & 0.7283 \\
\hline
\end{tabular}

Source: Researcher's Work (2020)

The probability of the Granger Causality test between tax revenue and GDP of 0.0373 and 0.22 is an indication of tax revenue significantly affecting GDP while GDP has no significant effect on TR in Nigeria; that is tax revenue granger cause GDP, while, Gross Domestic Product does not granger cause tax revenue. This implies that a unilateral causal effect relationship exist between tax revenue and Gross Domestic Product of Nigeria. On the contrary, the probability of the causality test between Gross Fixed Capital Formation and Gross Domestic Product ( $\rho$-values $=$ 0.48 and 0.22 ) which are insignificant at $10 \%$ chosen significant level implies that GFCF does not granger cause GDP and vice versa; the mean that there is no causal relationship between GFCF and GDP of Nigeria.

According to the stationary test conducted, which showed that GFCF is stationary at level while TR and GDP are stationary at first difference; the relationship between TR, GFCF and GDP is better analysed using ARDL but due to non-existence of significant relationship between GFCF, being the control variable, and GDP based on granger causality test conducted, the long run relationship could be better estimated using OLS.

\subsection{Regression Result}

Model One:

VAR Equation:

$$
\Delta \mathrm{GDP}_{\mathrm{t}}=5.37+\sum_{i=1}^{p-2} 2.32 \Delta \mathrm{TR}_{\mathrm{t}}+\epsilon_{\mathrm{t}}
$$


OLS long run Equation:

$$
\Delta \mathrm{GDP}_{\mathrm{t}}=5.37+2.32 \Delta \mathrm{TR}_{\mathrm{t}}+\mu_{\mathrm{t}}
$$

With Control Variable:

VAR Equation:

OLS long run Equation:

$$
\Delta \mathrm{GDP}_{\mathrm{t}}=6.77+\sum_{i=1}^{p-1} 2.35 \Delta \mathrm{TR}_{\mathrm{t}}+\sum_{i=1}^{p-1} 0.74 \Delta \mathrm{GFCF}_{\mathrm{t}}+\epsilon_{\mathrm{t}}
$$

$$
\Delta \mathrm{GDP}_{\mathrm{t}}=6.77+2.35 \Delta \mathrm{TR}_{\mathrm{t}}+0.74 \Delta \mathrm{GFCF}_{\mathrm{t}}+\mu_{\mathrm{t}}
$$

\begin{tabular}{|c|c|c|c|c|c|}
\hline \multirow{2}{*}{\multicolumn{2}{|c|}{ VARIABLES }} & \multicolumn{2}{|l|}{ Model 1} & \multicolumn{2}{|l|}{ Model 2} \\
\hline & & VAR & $O L S(G L M)$ & VAR & $O L S(G L M)$ \\
\hline \multirow[t]{4}{*}{ DTR } & Coeff. & 2.32 & 2.32 & 2.35 & 2.35 \\
\hline & Std. Error & 0.41 & 0.41 & 0.42 & 0.42 \\
\hline & t-stat. & 5.63 & 5.63 & 5.65 & 5.65 \\
\hline & P-value & & 0.00 & & 0.00 \\
\hline \multirow[t]{4}{*}{ GFCF } & Coeff. & & & 0.74 & 0.74 \\
\hline & Std. Error & & & 0.92 & 0.92 \\
\hline & t-stat. & & & 0.81 & 0.81 \\
\hline & P-value & & & & 0.42 \\
\hline \multirow[t]{4}{*}{ Constant } & Coeff. & 5.37 & 5.37 & 6.77 & 6.77 \\
\hline & Std. Error & 4.39 & 4.39 & 4.74 & 4.74 \\
\hline & t-stat. & 1.22 & 1.22 & 1.43 & 1.43 \\
\hline & $\mathrm{P}$-value & & 0.00 & & 0.15 \\
\hline \multicolumn{2}{|c|}{ Observations } & 38 & 38 & 38 & 38 \\
\hline \multicolumn{2}{|c|}{ R-squared } & 0.4753 & 0.4753 & 0.4851 & 0.4851 \\
\hline \multicolumn{2}{|c|}{ Adjusted R-squared } & 0.4603 & 0.4603 & 0.4548 & 0.4548 \\
\hline \multicolumn{2}{|c|}{ F-test [P-value] } & F-Stat $=31.70$ & F-Stat $=31.70[0.00]$ & F-Stat $=16.02$ & F-Stat $=16.02[0.00]$ \\
\hline
\end{tabular}

The results of the VAR estimates and that of the Ordinary Least Square Analyses are presented in Table 7.

Table 7. Regression results

Source: Researcher's Work (2020)

From the review of the diagnostic tests carried out, it is evident that there is serial correlation problem in the model. This is corrected for by examining the relationship between tax revenue and economic growth in Nigeria using Ordinary Least Square (Generalised Linear Model) according to Phillips and Ouliaris (1990). The result of the VAR and OLS estimation showed the same statistics, this is an indication that the equation converged in the long run.

From the result of the analysis carried out as presented in Table 7, Gross Domestic Product of Nigeria is positively and significantly influenced by revenue generated from taxes. The $\beta$-value of 2.32 implies that a dollar change in tax revenue causes \$2.32 incremental change in GDP. The coefficient of determination explains the degree of variations in the dependent variable (Gross Domestic Product) caused by the independent variable (tax revenue), $R^{2}$ of 0.4753 means that $47.53 \%$ change in GDP is as a result of changes that occurred in tax revenue while the remaining $52.47 \%$ changes in GDP is caused by other factor(s) not within the scope of this study.

Gross Fixed Capital Formation was introduced into the model, the result revealed that GFCF exerted insignificant positive effect on GDP $(\beta=0.74)$ with probability value of 0.42 . Looking at the coefficient of multiple determination (Adjusted R-squared), this explained the variation in GDP that was led by the joint variation in TR and GFCF; the statistical value of 0.4548 implies that $45.48 \%$ changes in GDP could only be explained by variations in tax revenue and Gross Fixed Capital Formation while the remaining 54.52\% are as a result of other factors outside the scope of this study. Also, the coefficient of multiple determination (Adjusted R-squared), of 0.4548 derived when GFCF was introduced, as compared to the adjusted R-squared of the based model (0.4603) showed that GFCF lessened the effect of TR on GDP as the causal variation in GDP dropped with the inclusion of GFCF in the equation. The difference in the adjusted R-squared prior and after then inclusion of GFCF showed a dwindling variation in GDP by 
approximately $1 \%$; GFCF weakened the explanatory power of the model approximately by $1 \%$. The probability of the F-statistics $(\rho=0.00)$ implies that tax revenue, controlling for GFCF significantly influences GDP of Nigeria.

\section{Discussion}

This study discovered that positive and significant relationship exists between revenue generated through taxes in Nigeria and its Gross Domestic product (GDP). This finding aligned with the assertion of Asaolu, et al., (2018) which concluded that the role of taxation in nation's building is irreplaceable. Taxation remains a strong socio political and economic tool for economic prosperity. Similar results were reported by Duncan (2019) in his bi-directional study between tax reforms and economic growth in Nigeria from a period of 1964-2016. Likewise, Akintoye and Tashie (2013) asserted that government can balance up with the nation's expenditure within the set time if revenue generate through taxes is increased. The findings of this study also supported other previous studies conducted in Nigeria like Ukpabi (2019) which delved on the impact of indirect taxes on economic growth in Nigeria using time series data from 1981 to 2018; Ionkwe and Agu (2019) which investigated the relationship between total tax revenue and economic growth in Nigeria using time series data from 1986-2016; Azubike and Onukwube (2019) which considered the effect of tax revenue using time series data for 15 years between 2002 and 2016.

On the contrary, the result negates the reports of Samuel, et al., (2019) which used eleven years (2003-2013) time series data to explore the implications of tax revenue on economy growth in Nigeria; and reported that tax revenue was not a predominant factor impacting on the Nigerian economy because of its insignificant positive effect; likewise, Oshiobugie and Akpokerere (2019) which negative and insignificant effect of the tax revenue components on economic growth using time series data from 2000 to 2017; also, Iorpev, et al., (2019) in their study analysis of the effect of tax revenue on Nigerian economic growth using time series data from 2002 to 2017; it discovered that individual components of taxes in Nigeria have no significant effect on economic growth but the total tax revenue significantly impacted the economy. The inconsistencies and contrasts in the result of Iorpev et al., (2019), Samuel, et al., (2019), and Oshiobugie and Akpokerere (2019) might be as a result of too short time frame used.

It is observed that $47.53 \%$ of the changes in real GDP of Nigeria is associated with changes in tax revenue. This is a reflection of diversifying economy. It means that other factors aside tax revenue led to the remaining 52.47\% variation. Economic growth is very important in the growth of any nation; hence it is applause to Nigeria economy. On the contrary, this percentage could be improved upon if the country can create a structured environment with reliable database, as this will help in capturing potential taxable persons not in the tax net. As much as Nigerian government is trying to promote indigenization, discouraging importation to improve our local market; enhancing revenue generated through tax system is a stimulus to economic growth. Also, Indigenization is not an easy task, but must be supported by necessary policies for its sustainability. There is wide room for improvement in Nigeria tax system as this will harness the growth in GDP, because there is a direct proportional relationship between tax revenue and economic growth in Nigeria.

It is evident from the findings that there are still loopholes in Nigeria tax system that needs to be addressed. This should catch the attention of practitioners, tax consultants both in public and private sectors; it is a pointer to the need of experts in improving the nation's tax system as well as mechanisms for tax revenue collections. It is an eye opener to other researchers to dig deep into other factors that could impact on Gross Domestic Product of Nigeria other than tax revenue.

\section{Conclusion and Recommendations}

This study examined the effect of tax revenue on economic growth From the series of analysis conducted using diverse statistical analytical techniques, the study therefore concluded that tax revenue has significant positive impact on the economic growth of Nigeria; likewise, Gross Fixed Capital Formation significantly controls the relationship between tax revenue and GDP of Nigeria. Based on the findings of this study, Nigerian government should create a structured environment with reliable database, as this will help in capturing potential taxable persons not in the tax net. As much as Nigerian government are trying to promote indigenization, discouraging importation to improve our local market; this should be supported by necessary policies for its sustainability. The government should resolve to peaceful conflict resolution to create a business-friendly and enabling environment for industrial revolution and economy diversifications in order to increase revenue generated via other means than taxes in order to spur economic growth. This will spring up employment opportunities, expand the tax net, increase the revenue generated through different components of taxes, while the end result will be economic expansion and growth. There is wide room for improvement in Nigeria tax system as this will harness the growth in GDP. 


\section{References}

Abomaye-Nimenibo, W. A. S., Michael, J. E. M., \& Friday, H. C. (2018). An empirical analysis of tax revenue and economic growth in Nigeria from 1980 to 2015. Global Journal of Human-Social Science, Political Science, $18(3), 8-40$.

Adams, O. K. (2019). Nigeria's economy challenges: Causes and way forward. IOSR Journal of Economics and Finance, 10(2), 78-82.

African Development Bank. (2018). African Economic Outlook. Retrieved February 10, 2020, from www.afdb.org

Akintoye, I. R., \& Tashie, G. A. (2013). The effect of tax compliance on economic growth and development in Nigeria. British Journal of Arts and Social Science, 11(2), 222-231.

Amadi, K. C., \& Alolote, I. A. (2019). The nomenclature of taxation in Nigeria: Implications for economic development. Journal of International Business Research and Marketing, 4(4), 28-33.

Amos, O. A., Uniamikogbo, E., \& Aigienohuwa, O. O. (2017). Tax revenue and economic growth of Nigeria. Scholars Journal of Economics, Business and Management, 4(10), 696-702.

Asaolu, T. O., Olabisi, J., Akinbode, S. O., \& Alebiosu, O. N. (2018). Tax revenue and economic growth in Nigeria. Scholedge International Journal of Management \& Development, 5(7), 72-85.

Azubike, J. U. B. (2009). Challenges of tax authorities, taxpayers in the management of tax reform processes. The Nigerian Accountant, 42(2), 36-42.

Cornelius, M. O., Ogar, A., \& Oka, F. A. (2016). The impact of tax revenue on economic growth: Evidence from Nigeria. IOSR Journal of Economics and Finance, 7(1), 32-38.

Dladla, K., \& Khobai, H. (2018). The impact of taxation on economic growth in South Africa. Nelson Mandela University, Department of Economics Working Papers Series. Working Paper No. 2018/18/86219. Munich Personal RePEc Archive. Retrieved from https://mpra.ub.uni-muenchen.de/86219/

Duncan, O. O. (2019). Revenue effects of tax reforms, economic growth and political environment in Kenya. African Journal of Economic Review, VII(I), 136-153.

Edewusi, D. G., \& Ajayi, I. E. (2019). The nexus between tax revenue and economic growth in Nigeria. International Journal of Applied Economics, Finance and Accounting, 4(2), 45-55.

Egbunike, F. C., Emudainohwo, O. B., \& Gunardi, A. (2018). Tax revenue and economic growth: A study of Nigeria and Ghana. Signifikan Journal Ilmu Ekonomi, 7(2), 213-220.

ESA. (2010). European system of national and regional accounts. Retrieved from https://ec.europa.eu/eurostat/statistics explained/index.php?title=Glossary:ESA_2010

Gale, W. G., \& Samwick, A. A. (2016). Effects of income tax changes on economic growth. Retrieved February 23, 2020, from https://www.brookings.edu/research/effects-of-income-tax-changes-on-economic-growth/

Gbato, A. (2017). Impact of taxation on growth in Sub-Saharan Africa: New evidence based on a new data set. Munich Personal RePEc Archive (MPRA), 80903, 1-29. Retrieved January 14, 2020, from https://mpra.ub.uni-muenchen.de/80903/

Herbert, W. E., Nwarogu, I. A., \& Nwabueze, C. C. (2018). Tax reforms and Nigeria's economic stability. International Journal of Applied Economics, Finance and Accounting, 3(2), 74-87.

International Monetary Fund (IMF). (2019). Regional Economic Outlook: Sub-Saharan Africa. Retrieved January 26, 2020, from www.imf.org

International Monetary Fund (IMF). (2019). World Economic Outlook. Retrieved February 22, 2020, from www.imf.org.on

Iorpev, L., Azende, T., \& Matthew, N. V. (2019). Analysis of the effect of tax revenue on Nigerian economic growth. AE-Funai Journal of Accounting, Business and Finance, 9(1), 128-142.

Ironkwe, U. I., \& Agu, E. O. (2019). Tax revenue and economic development in Nigeria. International Journal of Advanced Academic Research, 5(4), 1-15.

Jhinghan, M. I. (2004). Money, Banking, International Trade and Public Finance. New Delhi: Tata McGraw Hill.

Liew, V. K. (2004). Which lag length selection criteria should we employ?. Economics Bulletin, 3(33), 1-9. 
Lin, B., \& Jia, Z. (2019). Tax rate, government revenue and economic performance: A perspective of Laffer curve. China Economic Review, 56(1), 1-20.

Lucas, R. E. (1988). On the mechanics of economic development. Journal of Monetary Economics, 22(1), 3-42.

National Bureau of Statistics. (2018). Nigerian Gross Domestic Product. Retrieved February 22, 2020, from www.nigerinstat.gov.ng

OECD. (2018). Tax policies for inclusive growth in a changing world. Retrieved February 7, 2020, from www.oecd.org/income-distribution-database/

OECD. (2019). Revenue Statistics in Africa. Retrieved February 21, 2020, from http://oe.cd/revenue-statistics-in-africa

Ogho, O. (2007). Economic growth or economic development?. Business Day online. Retrieved December 29, 2019, from https://www.google.com/search?q=BusinessDay+online,+October+17+2010\&tbm

Okwu, A. T., Oseni, I. O., Aberu, F., \& Obiakor, R. T. (2017). Real gross domestic of Nigeria (2017-2030): Autoregressive integrated moving average (ARIMA) model-based forecasts. Babcock Journal of Economics, 6, 100-113.

Ola, C. S. (2001). Income Tax Low and Practice in Nigeria. Ibadan: Heinenmann Educational Books (Nigeria) Plc.

Oshiobugie, O. B., \& Akpokerere, O. E. (2019). Tax revenue and the Nigerian economy. International Journal of Academic Management Science Research, 3(2), 61-66.

Osho, A. E., \& Efuntade, A. O. (2019). Impact of taxation on investment, social and economic development in Nigeria. Global Scientific Journal, 7(11), 44-60.

Phillips, P. C. B., \& Ouliaris, S. (1990). Asymptotic properties of residual based tests for cointegration. Econometrica, Econometric Society, 58(1), 165-193.

Romer, P. (1986). Increasing returns and long-run growth. Journal of Political Economy, 94(1), 1002-1037.

Romer, P. (1990). Endogenous technological changes. Journal of Political Economy, 98(1), 71-103

Samuel, O. J., Adewole, J. A., \& Idih, O. E. (2019). Implications of tax revenue on economy growth in Nigeria. American International Journal of Economics and Finance Research, 1(2), 1-16.

Ukpabi, A. L. (2019). Impact of indirect taxation on economic growth in Nigeria. International Journal of Advanced Engineering Research and Science, 6(5), 54-61.

Uzoka, P. U., \& Chiedu, C. O. (2018). Effect of tax revenue on economic growth of Nigeria. International Journal of Social Sciences and Management Research, 4(7), 17-24.

World Bank. (2016). World Development Indicators. Washington DC: The World Bank. Retrieved January 8, 2020 , from http://www.un.org/en/development/desa/population/migration/events/coordination/7/docs/P11_IOM.pdf and www.worldbank.org/indicator/

World Bank. (2018). World Development Indicators. Washington DC: The World Bank. Retrieved February 21, 2020, from https://data.worldbank.org/indicator/GC.TAX.TOTL.GD.ZS

World Bank. (2019). Mobilising tax resources to boost growth and prosperity in sub-saharan Africa. Washington DC: The World Bank. Retrieved January 8, 2020, from https://www.worldbank.org/en/results/2019/09/09/

World Bank. (2019). World Development Indicators. Washington DC: The World Bank. Retrieved February 21, 2020, from http://wdi.worldbank.org/table/WV.1

World Bank. (2020). Global Economic Prospects. Retrieved January 8, 2020, from www.worldbank.org

Wosowei, F. (2013). Fiscal deficits and macroeconomic aggregates in Nigeria. Kuwait Chapter of Arabian Journal of Business and Management Review, 2(9), 72-82.

\section{Copyrights}

Copyright for this article is retained by the author(s), with first publication rights granted to the journal.

This is an open-access article distributed under the terms and conditions of the Creative Commons Attribution license (http://creativecommons.org/licenses/by/4.0/). 